\title{
Pengaruh Harga dan Kualitas Pelayanan Terhadap Kepuasan Pelanggan Pada PT. TIKI JNE Sub Agen Kayuagung
}

\author{
Dewi Sukaesih ${ }^{1}$, Agus Mulyani ${ }^{2}$, Benny Usman ${ }^{3}$ \\ ${ }^{1}$ Manajemen, Fakultas Ekonomi Universitas PGRI Palembang \\ ${ }^{2}$ Manajemen, FE Universitas PGRI Palembang, agusmulyani@univpgri-palembang.ac.id \\ ${ }^{3}$ Manajemen, FE Universitas PGRI Palembang, benny usman@univpgri-palembang.ac.id
}

\begin{abstract}
ABSTRAK
Penelitian ini bertujuan untuk mengetahui pengaruh harga dan kualitas pelayanan terhadap kepuasan pelanggan PT. TIKI JNE Sub Agen Kayuagung, baik secara simultan maupun parsial. Permasalah dalam penelitian ini adalah pelayanan ketepatan waktu sampainya pengiriman masih kurang baik namun tidak begitu buruk dikarenakan ketepatan waktu sampai terkadang tidak sesuai dengan jangka waktu yang telah ditetapkan. Berdasarkan hasil uji regresi berganda yaitu koefisien korelasi dan determinasi mempunyai hubungan antara variabel bebas dan variabel terikat mempunyai hubungan kuat. Hasil pengujian secara parsial diketahui bahwa nilai signifikansi sebesar 0,000 $<0,05$ artinya Ho ditolak, Ha diterima dapat disimpulkan bahwa terdapat pengaruh antara harga terhadap kepuasan pelanggan. Sedangkan nilai probabilitas signifikansi sebesar 0,550 >0,05 artinya Ho diterima, $\mathrm{Ha}$ ditolak maka dapat disimpulkan bahwa tidak terdapat pengaruh antara kualitas pelayanan terhadap kepuasan pelanggan. Sedangkan hasil pengujian secara simultan dengan uji- $F$ variabel harga (X1) dan kualitas pelayanan (X2) terhadap variabel kepuasaan pelanggan $(Y)$ karena sig $<\alpha=0,05$ atau $0,000<0,05$ maka Ho ditolak. Ha diterima. Artinya, dengan tingkat kesalahan sebesar $5 \%$ atau 0,05 dapat dinyatakan bahwa harga dan kualitas pelayanan berpengaruh terhadap kepuasan pelanggan secara simultan.
\end{abstract}

Kata kunci: Harga, Kualitas Pelayanan, dan Kepuasan Pelanggan

\begin{abstract}
This study aims to determine the effect of price and service quality on customer satisfaction PT. TIKI JNE Sub Kayuagung Agent both simultaneously and partially. The problem in this study is the service on time delivery until delivery is still not good but not so bad because the timeliness is sometimes not in accordance with a predetermined time period. Based on the results of multiple regression tests, the correlation coefficient and determination have a relationship between the independent variable and the dependent variable have a strong relationship. Partial test results note that the significance value of $0,000<0.05$ means that $\mathrm{Ho}$ is rejected, $\mathrm{Ha}$ is accepted, it can be concluded that there is an influence between price and customer satisfaction. While the significance value of $0.550>0.05$ means that Ho is accepted, $\mathrm{Ha}$ is rejected, it can be concluded that there is no influence between service quality on customer satisfaction. While the test results simultaneously with the F-test variable price $(X 1)$ and service quality $(X 2)$ on customer satisfaction variables $(Y)$ because sig $<\alpha=0.05$ or $0,000<0.05$ then Ho is rejected. Ha accepted. That is, with an error rate of $5 \%$ or 0.05 it can be stated that the price and quality of service affect customer satisfaction simultaneously.
\end{abstract}

Keywords: Price, Service Quality, and Customer Satisfaction

\section{A. PENDAHULUAN}

Industri jasa pengiriman barang merupakan industri yang tingkat pertumbuhannya sangat pesat tahun demi tahun. Hal ini bisa terlihat dari banyaknya perusahaan jasa yang terus bertambah dan berkembang pada saat ini. Perkembangan industri jasa pengiriman barang yang semakin pesat dewasa ini karena permintaan 
konsumen yang semakin meningkat dalam jasa pengiriman barang menimbulkan bertambahnya perusahaan yang memasuki pasar jasa untuk dapat bersaing dan bertahan.

Menghadapi kenyataan banyaknya jasa pengiriman barang yang sejenis diantaranya seperti PT. Ninja Express, PT. Tiki Jalur Nugraha Ekakurir (JNE), dan PT. Pos Indonesia terus bersaing untuk mendapatkan pelanggan dengan strategi pemasaran yang berbeda-beda.

Dalam industri jasa pengiriman barang, harga merupakan salah satu faktor penting yang mempengaruhi pemasaran suatu produk atau jasa. Tinggi rendahnya harga selalu menjadi perhatian utama para konsumen saat mereka mencari suatu produk atau jasa. Sehingga harga yang ditawarkan menjadi bahan pertimbangan khusus, sebelum mereka memutuskan untuk membeli barang maupun menggunakan suatu jasa.

Tidak hanya harga yang mempengaruhi pemasaran suatu produk atau jasa tetapi juga kualitas pelayanan. Seseorang akan merasa puas apabila kegiatan yang mereka lakukan dilayani dengan baik, sehingga dapat berdampak pada kepuasan.

PT. TIKI JNE Sub Agen Kayuagung merupakan perusahaan yang bergerak dibidang pengiriman barang dan logistik domestic melayani kiriman paket dan dokumen dengan tujuan dalam negeri dan luar negeri yang memanfaatkan transportasi tercepat yang tersedia dan melayani beragam jenis layanan sesuai kebutuhan konsumen.

PT. TIKI JNE Sub Agen Kayuagung memprioritaskan kualitas pelayanan jasa, karena berhubungan langsung dengan pelanggan atau pengguna jasa. Pelayanan yang berkualitas dan bermutu sangat berpengaruh pada aktifitas PT. TIKI JNE Sub Agen Kayuagung sendiri, para pelanggan atau pengguna jasa akan menilai apakah jasa itu baik dari kualitas pelayanan yang diberikan.

Kualitas pelayanan pada PT. TIKI JNE Sub Agen Kayuagung terlihat masih kurang baik, tetapi tidak buruk. Hal ini terlihat masih adanya antrian panjang pada saat melakukan transaksi baik penerimaan maupun pengiriman.

Dilihat dari permintaan konsumen akan pengiriman barang yang semakin meningkat, para konsumen tentunya mengharapkan harga yang kompetitif maupun kualitas pelayanan yang baik, yang nantinya akan berpengaruh pada kepuasan pelanggan atau pengguna jasa PT. TIKI JNE Sub Agen Kayuagung.

Salah satu cara untuk mencegah kemerosotan kualitas pelayanan sekaligus pengembangan ke arah positif adalah PT. TIKI JNE Sub Agen Kayuagung perlu meningkatkan kualitas pelayanan yang disesuaikan dengan harga yang kompetitif dalam menggunakan jasa pengiriman barang PT. TIKI JNE Sub Agen Kayuagung serta memberikan lingkungan kerja yang tentram dan harmonis agar individunya mampu berkomunikasi dengan baik.

Jika hal tersebut tidak dihiraukan oleh PT. TIKI JNE Sub Agen Kayuagung maka secara otomatis pelanggan atau pengguna jasa $\mathrm{PT}$. TIKI JNE Sub Agen Kayuagung akan beralih kepada jasa pengiriman pesaing.

Kegiatan baik penerimaan maupun pengiriman PT. TIKI JNE Sub Agen Kayuagung. cenderung tidak stabil. PT. TIKI JNE Sub Agen Kayuagung.mempunyai 10 jenis layanan dan pada jenis layanan Money Remittance atau mengirim maupun 
menerima dalam bentuk uang yang paling menurun.

Alasan inilah yang mengharuskan PT. TIKI JNE Sub Agen Kayuagung harus menetapkan tarif harga yang sesuai serta kualitas pelayanan yang unggul dari para pesaing agar keberadaan PT. TIKI JNE Sub Agen Kayuagung akan tetap service sepanjang masa dan lebih meningkatkan kembali kualitas pelayanannya. Sehingga memberikan kepuasan bagi para pelanggan atau pengguna jasa.

\section{B. KAJIAN TEORI}

\section{1) Pengertian Harga}

Menurut Alma (2013:169)

mengemukakan bahwa : "Harga adalah nilai suatu barang yang dinyatakan dengan uang".

Menurut Malau (2017:125) Harga adalah nilai yang disebutkan dalam bentuk mata uang seperti rupiah, dinar atau dolar atau medium moneter lainnya sebagai nilai tukar.

Menurut Kasmir (2014:191) Harga merupakan sejumlah nilai (dalam mata uang) yang harus dibayar konsumen untuk membeli atau menikmati barang atau jasa yang ditawarkan. Penentuan harga merupakan salah satu aspek penting dalam kegiatan marketing mix.

Menurut Basu Swastha (2015:185) Harga adalah jumlah uang (ditambah beberapa barang kalau mungkin) yang dibutuhkan untuk mendapatkan sejumlah kombinasi dari barang beserta pelayanannya.

Berdasarkan pendapat para ahli diatas, disimpulkan jika Harga adalah nilai dari suatu barang yang dinyatakan dalam bentuk uang seperti rupiah, dinar atau dolar atau lainnya sebagai nilai tukar yang harus dibayar konsumen untuk membeli atau menikmati barang atau jasa yang ditawarkan.
2) Pengertian

Kualitas

\section{Pelayanaan}

Menurut Fandy Tjiptono (2014 :

268) "Kualitas pelayanan berfokus pada upaya pemenuhan kebutuhan dan keinginan konsumen serta ketepatan penyampaianya untuk mengimbangi harapan konsumen".

Menurut Abdullah (2017:44) Kualitas adalah keseluruhan ciri dan karakteristik suatu barang atau jasa yang berpengaruh pada kemampuannya untuk memuaskan kebutuhan yang dinyatakan maupun yang tersirat.

Menurut Hardiansyah (2011:11) dalam Riska Heriansah bahwa "Kualitas pelayanan dapat diartikan sebagai aktivitas yang diberikan untuk membantu, menyiapkan dan mengurus baik dari itu berapa barang atau jasa dari satu kepada pihak lain.

Menurut Lovelock (2010:154) "Kualitas pelayanan adalah hasil dari evaluasi dimana pelanggan membandingkan evaluasi mereka terhadap pelayanan dan hasilnya dengan apa yang mereka bayangkan.

Berdasarkan definisi menurut para ahli diatas maka dapat disimpulkan bahwa kualitas pelayanan adalah perbandingan antara pelayanan yang dirasakan (persepsi) konsumen dengan kualitas pelayanan yang diharapkan dan pengendalian atas tingkat keunggulan tersebut untuk memenuhi keinginan konsumen.

\section{3)}

\section{Pengertian Pelanggan}

Menurut Adam (2015:18) Kepuasan atau Ketidakpuasan pelanggan merupakan perbedaan / kesenjangan antara harapan sebelum pembelian dengan kinerja atau hasil yang dirasakan setelah pembelian.

Menurut Rai Utama (2017:98) Kepuasan pelanggan (costomer 
satisfaction) yaitu telah terjadi suatu kepercayaan umum, khususnya didunia bisnis, bahwa kepuasan pelanggan menjadi salah satu kunci keberhasilan suatu usaha. Hal ini dikarenakan dengan memuaskan konsumen, organisasi dapat meningkatkan tingkat keuntungannya dan mendapatkan pangsa pasar yang lebih luas.

Menurut Sudaryono (2016:96) Kepuasan Pelanggan ialah: hasil dari penilaian pelanggan bahwa produk atau jasa pelayanan telah memberikan tingkat kenikmatan dimana tingkat pemenuhan ini bisa lebih atau kurang.

Menurut Mubarok (2015:73)

Kepuasan Pelanggan adalah suatu keadaan dimana kebutuhan, keinginan, dan harapan konsumen terpenuhi melalui produk yang dikonsumsinya.

Dari definisi di atas menunjukkan bahwa Kepuasan pelanggan merupakan suatu pemenuhan harapan. Pelanggan dapat dikatakan puas dengan produk maupun pelayanan yang di berikan apabila harapan pelanggan akan produk/pelayanan yang di berikan tersebut telah sesuai bahkan melebihi harapan mereka.

\section{METODE PENELITIAN}

Menurut Sugiyono (2015:7) metode kuantitatif di namakan metode tradisional, karena metode ini sudah cukup lama digunakan sehingga sudah mentradisi sebagai metode untuk penelitian.

Metode ini disebut sebagai metode ilmiah/scientific karena telah memenuhi kaidah-kaidah ilmiah yaitu obyektif, terukur, rasional, dan sistematik. Metode ini juga disebut metode penemuan (discovery), karena dengan metode ini dapat ditemukan dan dikembangkan berbagai iptek baru. Metode ini disebut kuantitatif karena data penelitian berupa angkaangka dan analisis menggunakan statistik.

\section{1) Populasi dan Sampel}

a. Populasi

Menurut Sugiyono (2015:135) populasi adalah wilayah generalisasi yang terdiri atas: obyek/subyek yang mempunyai kuantitas dan karakteristik tertentu yang di tetapkan oleh peneliti untuk di pelajari dan kemudian di tarik kesimpulannya. Adapun populasi dalam penelitian ini adalah pelanggan pada PT. TIKI JNE Sub Agen Kayuagung.

b. Sampel

Menurut Sugiyono (2015:81), sampel adalah bagian dari jumlah dan karakteristik yang dimiliki oleh populasi tersebut. Karena jumlah populasi cukup banyak, maka penarikan sampel dalam penelitian ini menggunakan teknik Sampling Insidental.

Penentuan jumlah sampel menggunakan rumus Slovin yang dinyatakan dalam Riska Hariansah (2013:38) dengan rumus sebagai berikut:

$$
n=\frac{N}{1+N e^{2}}
$$

\section{Sumber : Riska Hariansah (2013:38)}

Dimana :

$\mathrm{n}$ : jumlah sampel.

$\mathrm{N}$ : jumlah populasi.

e: batas toleransi kesalahan (10\%)

Berdasarkan rumusan tersebut diperoleh jumlah sampel sebagai berikut :

$n=\frac{N}{1+N e^{2}}=\frac{1972}{1972(0.1)^{2}+1}=\frac{1972}{1972(0.01)+1}=\frac{1972}{20.72}=95.17$

Berdasarkan pendapat diatas, peneliti mengambil sampel dalam penelitian ini adalah sebanyak 95 responden 


\section{2) Teknik Pengumpulan Data}

Teknik pengumpulan data dalam penelitian ini menggunakan cara atau instrumen penelitian dalam mengumpulkan data-data, instrumen yang digunakan yaitu :

\section{a. Kuesioner}

Menurut Sugiyono (2015:216) Kuesioner merupakan suatu teknik pengumpulan data dengan memberikan atau menyebarkan daftar pertanyaan/pernyataan kepada responden dengan harapan memberikan respons atas daftar pertanyaan/pernyataan tersebut.

b. Observasi

Menurut Sugiyono (2015:214) sebagai teknik pengumpulkan data dengan cara langsung melakukan pengamatan secara langsung ke obyek penelitian yaitu PT. TIKI JNE Sub Agen Kayuagung guna mendapatkan data dan informasi yang berkaitan dengan pembahasan.

\section{3) Teknik Analisis Data}

Apabila pengumpulan data sudah dilakukan, maka data yang sudah terkumpul harus diolah data mengunakan program komputer SPSS (Statistical package for social sciences ver.22.0 for windows) dan di analisis.

Dengan skala Likert, maka variabel yang akan diukur dijabarkan menjadi indikator variabel. Sugiyono (2015:169), adapun penetapan skor sebagai berikut :

$\begin{array}{lll}\text { ST }=\text { Sangat Setuju } & \text { skor } & 5 \\ \text { S }=\text { Setuju } & \text { skor } & 4 \\ \text { CS }=\text { Cukup Setuju } & \text { skor } & 3 \\ \text { TS }=\text { Tidak Setuju } & \text { skor } & 2 \\ \text { STS= Sangat Tidak Setuju } & \text { skor } & 1\end{array}$

\section{Analisis Regresi Sederhana}

$$
\text { Sugiyono }
$$

mengemukakan regresi sederhana didasarkan pada hubungan fungsional ataupun kausal satu variabel independen dengan satu variabel dependen. Penelitian ini meregresikan variabel Harga dan variabel Kualitas Pelayanan dengan variabel Kepuasan Pelanggan. Secara umum persamaan regresi sederhana (dengan satu prediktor) dapat di rumuskan sebagai berikut :

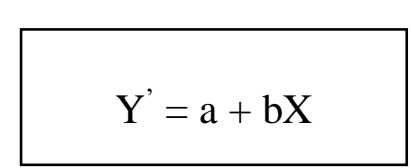

Sumber: Sugiyono (2015:293)

Keterangan :

$\mathrm{Y}^{\prime} \quad=$ nilai yang diprediksikan

a $=$ konstanta atau bila harga $\mathrm{X}=0$

$\mathrm{b}=$ koefisien regresi

$\mathrm{X}=$ nilai variabel independen

\section{Analisis Regresi Berganda}

Dalam penelitian ini di gunakan metode analisis berganda. Analisis regresi berganda dilakukan untuk mengadakan prediksi nilai dari variabel terikat yaitu Kepuasan pelanggan $(\mathrm{Y})$ dengan memperhitungkan variabel bebas yang terdiri dari Harga $\left(X_{1}\right)$ dan Kualitas Pelayanan $\left(X_{2}\right)$ berpengaruh terhadap Kepuasan Pelanggan $(\mathrm{Y})$. Menurut Sugiyono (2015:298). Secara umum persamaan regresi berganda dapat di rumuskan sebagai berikut :

$\mathrm{Y}^{\prime}=\mathrm{a}+\mathrm{b}_{1} \mathrm{X}_{1}+\mathrm{b}_{2} \mathrm{X}_{2}$

Sumber : Sugiyono (2015:298)

Keterangan :

$\mathrm{Y}^{\prime} \quad=$ nilai yang diprediksikan

a $=$ konstanta atau bila harga $\mathrm{X}=0$

$b_{1} b_{2}=$ koefisien regresi

$\mathrm{X}_{1} \quad=$ nilai variabel Harga

$\mathrm{X}_{2}=$ nilai variabel Kualitas Pelayanan

\section{Analisis Koefisien Korelasi}

Analisis koefisien korelasi digunakan untuk mengetahui hubungan antara variabel-variabel yang diteliti yaitu dengan mencari korelasi antara variabel independen dan dependen. 
Variabel independen dalam penelitian ini adalah harga, kualitas pelayanan. Sedangkan variabel dependen adalah kepuasan pelanggan. Koefisien korelasi sederhana dalam penelitian ini.

\section{Koefisien Determinasi Error! Reference source not found. Koefisien Determinasi Error!} Reference source not found. ini mengukur persentase total variasi variabel dependen $(\mathrm{Y})$ yang dijelaskan oleh variabel independen $(\mathrm{X})$ di dalam garis regresi. Besarnya koefisien determinasi Error! Reference source not found. ini adalah 0 sampai dengan 1 atau dalam persentase antara $0 \%$ sampai dengan $100 \%$. Nilai Error! Reference source not found. yang kecil berarti kemampuan variabel-variabel independen dalam menjelaskan variabel dependen amat terbatas, dan apabila nilai yang mendekati satu atau $100 \%$ berarti variabel-variabel independen memberikan hampir semua informasi yang dibutuhkan untuk memprediksi variabel dependen.

\section{Pengujian Hipotesis}

\section{Uji t (Secara Parsial)}

Uji t digunakan untuk mengetahui apakah variabel independen berpengaruh secara signifikan terhadap variabel dependen.Untuk mengikuti fungsi $t$ dengan derajat kebebasan (n-2). Rumus yang di gunakan Menurut Sugiyono (2015:299) sebagai berikut :Tingkat signifikansi menggunakan alpha $5 \%$ (signifikansi $5 \%$ atau 0,05 adalah ukuran standar yang sering di gunakan dalam penelitian.

Kriteria pengujian

- jika sig $<\alpha=0.05$ atau $5 \%$, Ho diterima, Ha ditolak berarti ada pengaruh yang signifikan
- jika sig> $\alpha=0.05$ atau $5 \%, \mathrm{Ho}$ ditolak, Ha diterima berarti tidak ada pengaruh yang signifikan.

\section{Uji F (Secara Simultan)}

Pada dasarnya uji statistik $F$ menunujukkan apakah semua variabel independen atau bebas mempunyai pengaruh secara bersama-sama (simultan) terhadap variabel dependen atau terikat.rumus yang di gunakan (Sugiyono, 2015:297) adalah sebagai berikut :

Kiteria pengujian

- Jika sig $<\alpha=0.05$ atau $5 \%$, Ho diterima, Ha ditolak berarti ada pengaruh yang signifikan

- Jika sig> $\alpha=0.05$ atau $5 \%$, Ho ditolak, Ha diterima berarti tidak ada pengaruh yang signifikan.

\section{HASIL PENELITIAN \\ a. Uji Validitas}

Menurut Sugiyono (2015:285) uji validitas adalah suatu ukuran yang menujukan tingkat kesahihan suatu tes. Kuesioner dikatakan sah atau valid jika pertanyaan pada kuesioner tersebut mampu mengungkapkan sesuatu yang akan diukur oleh kuesioner itu, uji signifikan dilakukan dengan membandingkan dengan nilai tabel. Jika sig $<\alpha=0,05$ item tersebut valid dan dapat dijadikan sebagai indikator terhadap variabel tersebut, dan jika sig $>\alpha=0,05$ maka item tersebut tidak valid dan tidak dapat dijadikan sebagai indikator terhadap variabel atau pernyataan tersebut dihilangkan.

Uji validitas dapat dilakukan dengan cara mengkorelasikan setiap butir dengan skor total yang merupakan tiap skor pertanyaan yang dijawab oleh responden dengan menggunakan rumus Rank Spearman yang ada dalam SPSS. Untuk mengukur validitas variabel pada 
penelitian ini, dilakukan uji coba instrumen dengan menggunakan 95 responden. Validitas instrumen dicari dengan menghitung nilai korelasi dengan Rank Spearman dalam program SPSS.

Dari hasil pengolahan data menggunakan SPSS For Windows Version 22 menunjukan bahwa hasil uji instrument dari 10 item pernyataan pada variabel harga keseluruhan dinyatakan valid dengan nilai sig $<\alpha=$ 0,05, sehingga keseluruhan item pernyataan yang ada pada instrument tersebut dapat dijadikan sebagai alat ukur yang valid dalam analisis selanjutnya.

$$
\text { Hasil pengolahan data }
$$
menggunakan SPSS For Windows Version 22 menunjukan bahwa hasil uji coba instrument dari 7 item pernyataan pada variabel kualitas pelayanan dinyatakan valid dengan nilai sig $<\alpha=$ 0,05 , sehingga item pernyataan yang ada pada instrument tersebut dapat diikut sertakan dalam analisis selanjutnya. Sedangkan hasil uji instrument diantara 10 item pernyataan pada variabel kualitas pelayanan dinyatakan tidak valid dengan nilai sig $>\alpha=0,05$ yaitu item pernyataan 6,7 dan 8 sehingga item pernyataan yang ada pada instrument tersebut tidak dapat diikut sertakan dalam analisis selanjutnya

Hasil pengolahan data menggunakan SPSS For Windows Version 22 menunjukan bahwa hasil uji coba instrument dari 10 item pernyataan pada variabel kepuasan pelanggan $(Y)$ keseluruhan dinyatakan valid dengan nilai sig $<\alpha=$ 0,05 , sehingga item pernyataan yang ada pada instrument tersebut dapat diikut sertakan dalam analisis selanjutnya.

\section{b. Uji Reliabilitas}

Reliabilitas adalah instrument yang bila di gunakan beberapa kali untuk mengukur objek yang sama, akan menghasilkan data yang sama. Sugiyono, (2015:205). Uji reliabilitas di hitung dengan menggunakan rumus koefisien Alpha Cronbach dengan program komputer SPSS ver.22.0 for windows adalah dengan membandingkan koefisien alpha $(\alpha)$ dengan 0,6 dengan ketentuan sebagai berikut

Tabel Hasil Uji Reliabilitas Instrumen Penelitian
\begin{tabular}{|l|c|c|c|}
\hline \multicolumn{1}{|c|}{ Variabel } & Cronbach's $\geq$ Alpha $(\boldsymbol{\alpha})$ & Keterangan \\
\hline $\begin{array}{l}\text { Harga (Error! Reference source } \\
\text { not found.) }\end{array}$ & 0.737 & 0.60 & Reliabel \\
\hline $\begin{array}{l}\text { Kualitas Pelayanan (Error! } \\
\text { Reference source not found.) }\end{array}$ & 0.686 & 0.60 & Reliabel \\
\hline Kepuasan Pelanggan (Y) & 0.863 & 0.60 & Reliabel \\
\hline
\end{tabular}

Sumber: Data Primer diolah SPSS, 2018

Uji reliabilitas di hitung dengan menggunakan rumus koefisien Alpha Cronbach dengan program komputer SPSS ver.22.0 for windows adalah dengan membandingkan koefisien alpha $(\alpha)$ dengan 0,6 dengan ketentuan, jika koefisien alpha
(Cronbach's $\geq 0,6$ ), maka $0.737 \geq 0,6$ yaitu variabel harga dan $0.686 \geq 0,6$ yaitu variabel kualitas pelayanan sedangkan $\mathbf{0 . 8 6 3} \geq 0,6$ yaitu variabel kepuasan pelanggan maka item tersebut reliabel, yang berarti bahwa pernyataan yang merupakan indikator 
dari variabel harga, kualitas pelayanan dan kepuasan pelanggan dalam penelitian ini adalah reliabel, dan layak dihandalkan pada analisa berikutnya.

\section{c. Uji Normalitas}

Menurut (Santoso,2012:53) untuk melakukan pengujian normalitas maka digunakan bantuan uji Skewness dan Kurtosis Pada tahapan pengujian normalnya masing-masing variabel. Rasio skewness dan rasio kurtosis dapat dijadikan petunjuk apakah suatu data berdistribusi normal atau tidak. Rasio skewness adalah nilai skewnes dibagi dengan standar error skewness, sedangkan rasio kurtosis adalah nilai kurtosis dibagi dengan standar error kurtosis. Sebagai pedoman, bila rasio kurtosis dan skewness berada diantara -2 hingga +2 , maka distribusi data adalah normal pengelolaan data mengunakan program komputer SPSS (Statistical package for social sciences ver.22.0 for windows).

Tabel Hasil Pengujian Normalitas Data

\begin{tabular}{|l|c|c|c|c|c|}
\hline \multirow{2}{*}{ Keterangan } & $\mathrm{N}$ & \multicolumn{2}{c|}{ Skewness } & \multicolumn{2}{c|}{ Kurtosis } \\
\cline { 2 - 6 } & Statistic & Statistic & Std. Error & Statistic & $\begin{array}{c}\text { Std. } \\
\text { Error }\end{array}$ \\
\hline Unstandardized & 95 &,- 595 &, 247 & 2,640 &, 490 \\
$\begin{array}{l}\text { Residual } \\
\text { Valid N (listwise) }\end{array}$ & 95 & & & & \\
\hline
\end{tabular}

Sumber: Data Primer, diolah SPSS, 2018

Pada table diatas terlihat bahwa masing-masing variabel penelitian yang terdiri dari harga, kualitas pelayanan dan kepuasan pelanggan, terlihat bahwa rasio skewness= $0,595 / 0,247=-0,240$, sedangkan rasio kurtosis $\mathbf{= 2 , 6 4 0 / 0 , 4 9 0 = 5 , 3 8 7}$. Karena rasio skewness dan rasio kurtosis berada diantara -2 hingga +2 , maka dapat disimpulkan bahwa distribusi data adalah normal. Sehingga dapat disimpulkan bahwa seluruh variable penelitian yang digunakan telah berdistribusi normal. Dengan demikian tahapan pengolahan data lebih lanjut dapat segera dilaksanakan.

\section{d. Uji Multikoloniearitas}

Uji multikolinearitas digunakan untuk mengetahui ada atau tidaknya penyimpangan asumsi klasik multikolinearitas yaitu adanya hubungan linear antar variabel bebas dalam model regresi. Prasyarat yang harus dipenuhi dalam model regresi adalah tidak adanya multikolinearitas. Pengujian multikolinearitas dengan melihat nilai variance inflation factor (VIF) pada model regresi dengan mengunakan program komputer SPSS (Statistical package for social sciences ver.22.0 for windows) :

Tabel Hasil Uji Multikolinearitas

\begin{tabular}{|c|l|c|c|}
\hline \multirow{2}{*}{ No. } & \multicolumn{1}{|c|}{ Variabel Bebas } & \multicolumn{2}{|c|}{ Collinearity Statistics } \\
\cline { 3 - 4 } & \multicolumn{1}{|c|}{ Tolerance } & VIF \\
\hline 1. & $\begin{array}{l}\text { Harga (Error! Reference source } \\
\text { not found.) }\end{array}$ & 0.999 & 1.001 \\
\hline 2. & $\begin{array}{l}\text { Kualitas Pelayanan (Error! } \\
\text { Reference source not found.) }\end{array}$ & 0.999 & 1.001 \\
\hline
\end{tabular}

a Dependent Variable: Kepuasan Pelanggan (Y)

Sumber: Data Primer diolah SPSS, 2018 
Dari hasil tabel diatas diketahui nilai variance inflation factor (VIF) kedua variabel yaitu variabel harga (Error! Reference source not found.) dan kualitas pelayanan (Error! Reference source not found.) adalah 1. 001, mendekati 1 atau bisa juga nilai VIF yaitu di sekitar angka 1, maka disimpulkan model regresi antar variabel bebas tidak terjadi multikolinearitas

\section{e. Uji Heteroskedasitas}

Uji heteroskedastisitas bertujuan menguji apakah dalam model regresi terjadi ketidaksamaan varians dari residual satu pengamatan ke pengamatan yang lain. Jika varians tetap maka disebut homoskedastisitas dan jika berbeda maka terjadi problem heteroskedastisitas. Model regresi yang baik yaitu tidak terjadi heteroskedastisitas.

Tabel Hasil Uji Heteroskedastisitas

\begin{tabular}{|c|l|c|}
\hline No. & \multicolumn{1}{|c|}{ Variabel Bebas } & $\begin{array}{c}\text { Unstandardized } \\
\text { Residual }\end{array}$ \\
\hline 1. & $\begin{array}{l}\text { Harga (Error! Reference source } \\
\text { not found.) }\end{array}$ & 0.731 \\
\hline 2. & $\begin{array}{l}\text { Kualitas Pelayanan (Error! } \\
\text { Reference source not found.) }\end{array}$ & 0.207 \\
\hline
\end{tabular}

a Dependent Variable: Kepuasan Pelanggan (Y)

Sumber: Data Primer diolah SPSS, 2018

Dari tabel diatas dapat diketahui korelasi antara variable harga (Error! Reference source not found.) dan kualitas pelayanan (Error! Reference source not found.) dengan unstandardized residual menghasilkan nilai signifikansi korelasi lebih besar dari $0.731>0.05$, dan korelasi antara variable Kualitas Pelayanan (Error! Reference source not found.) dengan unstandardized residual menghasilkan nilai signifikansi 0.207. Karena nilai signifikansi korelasi lebih besar dari 0.207> 0.05, maka dapat disimpulkan bahwa pada model regresi tidak ditemukan adanya masalah heteroskedastisitas.

\section{f. Hasil Analisis Data}

Data sudah dikumpulkan, diolah mengunakan program komputer SPSS (Statistical package for social sciences ver.22.0 for windows) dan dianalisis. Dalam pengolahan data ada beberapa langkah yang harus dilakukan antara lain :

\section{a) Hasil Koefisien Korelasi}

Analisis koefisien korelasi digunakan untuk mengetahui hubungan antara variabel-variabel yang diteliti yaitu dengan mencari korelasi antara variabel independen dan dependen. Variabel independen dalam penelitian ini adalah harga , kualitas pelayanan. Sedangkan variabel dependen adalah kepuasan pelanggan.

Menurut Wiratna (2014:127) koefisien korelasi digunakan untuk mengetahui hubungan antar variabel. Nilai koefisien korelasi dapat dilihat pada nilai $R$ yang ditunjukan pada tabel sebagai berikut : 
Tabel koefisien Korelasi

\begin{tabular}{|l|c|c|}
\hline \multicolumn{1}{|c|}{ Variabel } & $\begin{array}{c}\text { Pearson } \\
\text { Correlation }\end{array}$ & Tingkat Hubungan \\
\hline $\begin{array}{l}\text { Harga dan Kualitas } \\
\text { Pelayanan terhadap } \\
\text { kepuasan Pelanggan }\end{array}$ & 0,631 & Hubungan Kuat \\
\hline $\begin{array}{l}\text { Harga terhadap Kepuasan } \\
\text { Pelanggan }\end{array}$ & 0,630 & Hubungan Kuat \\
\hline $\begin{array}{l}\text { Kualitas Pelayanan terhadap } \\
\text { Kepuasan Pelanggan }\end{array}$ & 0,062 & Sangat Rendah \\
\hline
\end{tabular}

Sumber : Data primer yang diolah SPSS, 2018

Berdasarkan tabel di atas dapat dilihat bahwa nilai $R$ sebesar 0,631 yang menunjukkan bahwa derajat hubungan (korelasi) antara variabel harga dan kualitas pelayanan terhadap kepuasan pelanggan memiliki tingkat hubungan kuat. Hubungan variabel independen dengan variabel dependen dikatakan kuat karena berada pada interval 0,60-0,779.

Sedangkan hasil uji di atas dapat dilihat bahwa nilai $R$ sebesar 0,062 yang menunjukkan bahwa derajat hubungan (korelasi) antara variabel kualitas Pelayanan terhadap kepuasan Pelanggan memiliki tingkat hubungan sangat rendah. Hubungan variabel independen dengan variabel dependen dikatakan sangat rendah karena berada pada interval 0,00-0,199.

b) Analisis Koefisien Determinasi

Menurut Sugiyono (2015:230), koefisien determinasi ini mengukur persentase total variasi variabel dependen ( $\mathrm{Y}$ ) yang dijelaskan oleh variabel independen $(\mathrm{X})$ di dalam garis regresi. Besarnya koefisien determinasi ini adalah 0 sampai dengan 1 atau dalam persentase antara $0 \%$ sampai dengan $100 \%$. Nilai yang kecil berarti kemampuan variabel-variabel independen dalam menjelaskan variabel dependen amat terbatas, dan apabila nilai yang mendekati satu atau $100 \%$ berarti variabel-variabel independen memberikan hampir semua informasi yang dibutuhkan untuk memprediksi variabel dependen.

Koefisien determinasi ini digunakan untuk mengetahui apakah ada pengaruh variabel bebas terhadap variabel terikatnya. Nilai koefisien determinasi untuk variable bebas digunakan $R$ Square, sebagai berikut:

Tabel Hasil Koefisien Determinasi Variabel Harga, Kualitas Pelayanan Terhadap Kepuasaan Pelanggan Model Summary

\begin{tabular}{|r|r|r|r|}
\hline \multicolumn{1}{|c|}{$R$} & R Square & $\begin{array}{c}\text { Adjusted R } \\
\text { Square }\end{array}$ & $\begin{array}{c}\text { Std. Error of the } \\
\text { Estimate }\end{array}$ \\
\hline, $631^{\mathrm{a}}$ &, 399 &, 386 & 4,43529 \\
\hline
\end{tabular}

a. Predictors: (Constant), Kualitas Pelayanan, Harga

Sumber : Data primer diolah SPSS, 2018

Hasil analisis Koefisien determinasi dengan menggunakan program SPSS model summary menunjukan bahwa besarnya $R$ Square adalah 0,399 atau 39,9\% dalam hal ini variabel harga dan 
kualitas pelayanan mempunyai kontribusi terhadap variabel kepuasan pelanggan, sedangkan sisanya sebesar $(39,9-100 \%)=60,1 \%$ dipengaruhi oleh faktor- faktor lain yang tidak termasuk dalam penelitian ini.

Tabel Hasil Koefisien Determinasi Variabel Harga Terhadap Kepuasan Pelanggan Model Summary

\begin{tabular}{|c|r|r|r|}
\hline $\mathrm{R}$ & R Square & $\begin{array}{c}\text { Adjusted } \\
\text { R Square }\end{array}$ & $\begin{array}{c}\text { Std. Error of the } \\
\text { Estimate }\end{array}$ \\
\hline, $630^{\mathrm{a}}$ &, 397 &, 391 & 4,41721 \\
\hline
\end{tabular}

a. Predictors: (Constant), Harga

Sumber : Data primer diolah SPSS, 2018

Hasil analisis Koefisien determinasi dengan menggunakan program SPSS model summary menunjukan bahwa besarnya $R$ Square adalah 0,397 atau $39,7 \%$ dalam hal ini variabel harga mempunyai kontribusi terhadap variabel kepuasan pelanggan sedangkan sisanya sebesar $(\mathbf{3 9}, \mathbf{7} \%$ $100 \%)=60,3 \%$ dipengaruhi oleh faktor- faktor lain yang tidak termasuk dalam penelitian ini.

\section{Tabel Hasil Koefisien Determinasi Variabel Kualitas Pelayanan Terhadap Kepuasan Pelanggan Model Summary

\begin{tabular}{|c|r|r|r|}
\hline$R$ & R Square & $\begin{array}{c}\text { Adjusted R } \\
\text { Square }\end{array}$ & $\begin{array}{c}\text { Std. Error of the } \\
\text { Estimate }\end{array}$ \\
\hline, $062^{\mathrm{a}}$ &, 004 &,- 007 & 5,67780 \\
\hline
\end{tabular}

a. Predictors: (Constant), Kualitas Pelayanan

Sumber : Data primer diolah SPSS, 2018

Analisis koefisien determinasi dengan menggunakan program SPSS model summary menunjukan bahwa besarnya $\mathrm{R}$ Square adalah 0,004 atau $0,4 \%$ dalam hal ini variabel kualitas pelayanan mempunyai kontribusi terhadap variabel kepuasan pelanggan. Sedangkan sisanya sebesar $(0,4-100 \%)=9,96 \%$ dipengaruhi oleh faktor- factor lain dari penelitian ini yang tidak termasuk dalam penelitian ini.

\section{c) Hasil Pengujian Regresi Linear Sederhana}

Menurut Santoso (2012:89), Hasil pengujian secara parsial dengan uji-t variabel bebas dan terhadap variabel terikat (Y) karena sig $<\alpha=0,05$ uji-t digunakan untuk mengetahui apakah variabel bebas (X) secara parsial berpengaruh terhadap variabel terikat $(\mathrm{Y})$. 
Tabel Harga Terhadap Kepuasan Pelanggan Coefficients $^{a}$

\begin{tabular}{|l|r|r|r|r|r|}
\hline \multirow{2}{*}{ Variabel } & \multicolumn{2}{|c|}{$\begin{array}{c}\text { Unstandardized } \\
\text { Coefficients }\end{array}$} & $\begin{array}{c}\text { Standardized } \\
\text { Coefficients }\end{array}$ & \multirow{2}{*}{$\mathrm{t}$} & \multirow{2}{*}{ Sig. } \\
\cline { 2 - 4 } & \multicolumn{1}{|c|}{ B } & Std. Error & \multicolumn{1}{c|}{ Beta } & & \\
\hline (Constant) & 6,691 & 3,712 & & 1,802 &, 075 \\
Harga &, 814 &, 104 &, 630 & 7,826 &, 000 \\
\hline
\end{tabular}

a. Dependent Variable: Kepuasan Pelanggan

Sumber: Data primer diolah SPSS, 2018

Hasil pengujian secara parsial ujit variabel Harga dan terhadap variabel Kepuasan pelanggan ( $\mathrm{Y})$ karena sig $<\alpha=0,05$ atau $\mathbf{0 , 0 0 0}<\mathbf{0 , 0 5}$ maka Ho ditolak. Ha diterima. Artinya, dengan tingkat kesalahan sebesar $5 \%$ atau 0,05 dapat dinyatakan bahwa harga berpengaruh terhadap kepuasan pelanggan, maka dapat disimpulkan bahwa harga terhadap kepuasan pelanggan. hasil menunjukkan rangkuman model regresi yang dibentuk berdasarkan hasil koefisien regresi untuk variabel harga terhadap kepuasan pelanggan ( $\mathrm{Y}$ ) diperoleh koefisien dengan nilai $\mathbf{a}$ (Constant) $=$ 6,691 B = 0, 814 .

Berdasarkan hasil uji signifikansi di atas, maka persamaan sub struktur regresi yang mencerminkan variable dalam penelitian ini adalah :

$$
Y=6,691+0,814 X 1+e
$$

\section{Tabel Kualitas PelayananTerhadap Kepuasan Pelanggan} Coefficients $^{\mathrm{a}}$

\begin{tabular}{|c|c|c|c|c|c|}
\hline \multirow{2}{*}{ Variabel } & \multicolumn{2}{|c|}{$\begin{array}{l}\text { Unstandardized } \\
\text { Coefficients }\end{array}$} & \multirow{2}{*}{$\begin{array}{c}\text { Standardized } \\
\text { Coefficients } \\
\text { Beta }\end{array}$} & \multirow{2}{*}{$\mathrm{T}$} & \multirow{2}{*}{ Sig. } \\
\hline & B & $\begin{array}{l}\text { Std. } \\
\text { Error }\end{array}$ & & & \\
\hline $\begin{array}{l}\text { (Constant) } \\
\text { Kualitas } \\
\text { Pelayanan }\end{array}$ & $\begin{array}{r}32,163 \\
, 125\end{array}$ & $\begin{array}{r}5,635 \\
, 208\end{array}$ & 062 & $\begin{array}{r}5,708 \\
, 600\end{array}$ & $\begin{array}{l}, 000 \\
, 550\end{array}$ \\
\hline
\end{tabular}

a. Dependent Variable: Kepuasan Pelanggan

Sumber: Data primer diolah (2018)

Hasil pengujian secara parsial di atas dapat diketahui bahwa kualitas pelayanan mempunyai nilai probabilitas signifikansi sebesar $0,550>0,05$ artinya $\mathrm{Ho}$ diterima, $\mathrm{Ha}$ ditolak dengan tingkat kesalahan sebesar $5 \%$ atau 0,05 , maka dapat disimpulkan bahwa tidak terdapat pengaruh antara kualitas pelayanan terhadap kepuasan pelanggan hasil menunjukkan rangkuman model regresi yang dibentuk berdasarkan hasil koefisien regresi untuk variabel kualitas pelayanan (Error! Reference source not found.) terhadap kepuasan pelanggan ( $\mathrm{Y}$ ) diperoleh koefisien dengan nilai $\mathbf{a}$ (Constant) $=$ 32,163 $\mathrm{B}=\mathbf{0 , 1 2 5}$.

Berdasarkan hasil uji signifikansi di atas, maka persamaan sub struktur regresi yang mencerminkan variabel dalam penelitian ini adalah : 


$$
Y=32,163+0,125 \times 2+e
$$

\section{d) Hasil Pengujian Regresi \\ Berganda}

Dalam penelitian ini di gunakan metode analisis berganda. Analisis regresi berganda dilakukan untuk mengadakan prediksi nilai dari variabel terikat yaitu kepuasan pelanggan $(\mathrm{Y})$ dengan memperhitungkan variabel bebas yang terdiri dari harga $\left(X_{1}\right)$ dan kualitas pelayanan $\left(\mathrm{X}_{2}\right)$. Analisis regresi berganda dilakukan untuk mencari nilai pengaruh dua variabel bebas atau lebih terhadap variabel terikat. Besarnya pengaruh tersebut dapat dilihat pada tabel dibawah ini :

Menurut Santoso (2012:78), uji$\mathrm{F}$ digunakan untuk mengetahui apakah variabel bebas dan secara simultan berpengaruh terhadap variabel terikat (Y). Hipotesis pada pengujian yang digunakan adalah :

\section{Tabel Hasil Pengujian Secara Simultan Dengan Uji-F Anova}

\begin{tabular}{|l|r|r|r|c|c|}
\hline Keterangan & \multicolumn{1}{|c|}{$\begin{array}{c}\text { Sum of } \\
\text { Squares }\end{array}$} & \multicolumn{1}{|c|}{ Df } & $\begin{array}{c}\text { Mean } \\
\text { Square }\end{array}$ & F & Sig. \\
\hline Regression & 1199,875 & 2 & 599,938 & 30,497 &, $000^{\mathrm{b}}$ \\
Residual & 1809,809 & 92 & 19,672 & & \\
Total & 3009,684 & 94 & & & \\
\hline
\end{tabular}

a. Dependent Variable: Kepuasan Pelanggan

b. Predictors: (Constant), Kualitas Pelayanan, Harga

Sumber : Data primer diolah SPSS, 2018

Hasil pengujian secara simultan dengan uji- $F$ variabel bebas dan terhadap variabel terikat $(\mathrm{Y})$ karena sig $<\alpha=0,05$ atau $0,000<0,05$ maka $\mathrm{Ho}$ ditolak. Ha diterima. Artinya, dengan tingkat kesalahan sebesar 5\% atau0,05 dapat dinyatakan bahwa harga dan kualitas pelayanan berpengaruh terhadap kepuasan pelanggan secara simultan.

Menurut Santoso (2012:78), uji-t digunakan untuk mengetahui apakah variabel bebas dan secara parsial berpengaruh terhadap variabel terikat (Y). Hipotesis pada pengujian yang digunakan adalah :

\section{Tabel Analisis Regresi Linier Berganda}

Variabel Harga (Error! Reference source not found.), Kualitas Pelayanan (Error! Reference source not found.) Terhadap Kepuasan Pelanggan( $Y$ )

\section{Coefficients $^{\mathrm{a}}$}

\begin{tabular}{|c|c|c|c|c|c|}
\hline \multirow[t]{2}{*}{ Variabel } & \multicolumn{2}{|c|}{$\begin{array}{l}\text { Unstandardized } \\
\text { Coefficients }\end{array}$} & \multirow{2}{*}{$\begin{array}{c}\text { Standardized } \\
\text { Coefficients } \\
\text { Beta }\end{array}$} & \multirow[t]{2}{*}{$\mathrm{T}$} & \multirow[t]{2}{*}{ Sig. } \\
\hline & B & Std. Error & & & \\
\hline (Con & 4,594 & 5,653 & & ,813 & ,418 \\
\hline Harg & ,812 & 104 & ,629 & 7,772 &, 000 \\
\hline $\begin{array}{l}\text { Kualitas } \\
\text { Pelavanan }\end{array}$ & ,080 & ,163 & ,040 & ,493 & ,623 \\
\hline
\end{tabular}

a. Dependent Variable: Kepuasan Pelanggan

Sumber : Data primer diolah SPSS, 2018 
Hasil menunjukkan rangkuman model regresi yang dibentuk berdasarkan hasil koefisien regresi untuk variabel harga dan kualitas pelayanan terhadap kepuasan pelanggan $(Y)$ maka diperoleh nilai yaitu : a (Constant) $=4,594, B 1=0$, 812, $\mathbf{B 2}=0,080$. Hasil pengujian di atas dapat diketahui bahwa variabel harga terhadap kepuasan pelanggan mempunyai nilai probabilitas signifikansi sebesar $0,000<0,05$ artinya Ho diterima, Ha ditolak dengan tingkat kesalahan sebesar $5 \%$ atau 0,05, maka dapat disimpulkan bahwa harga berpengaruh terhadap kepuasan pelanggan secara parsial.

Hasil pengujian di atas dapat diketahui bahwa variabel kualitas pelayanan terhadap kepuasan pelanggan mempunyai nilai probabilitas signifikansi sebesar 0,623 $>$ 0,05 artinya Ho ditolak, Ha diterima dengan tingkat kesalahan sebesar 5\% atau 0,05, maka dapat disimpulkan bahwa kualitas pelayanan tidak berpengaruh terhadap kepuasan pelanggan secara parsial.

Berdasarkan hasil uji signifikansi di atas, maka persamaan sub struktur regresi yang mencerminkan variabel dalam penelitian ini diperoleh koefisien dengan nilai adalah :

$$
Y=4,594+0,812 X 1+0,080 X 2+e
$$

\section{E. PEMBAHASAN}

Berdasarkan hasil penelitian di atas permasalahan penelitian merupakan yang akan diteliti dapat diketahui bahwa "Pengaruh Harga Dan Kualitas Pelayanan Tehadap Kepuasan Pelanggan Pada PT. TIKI JNE Sub Agen Kayuagung ". Untuk analisis data responden, digunakan tabel frekuensi untuk melihat komposisi jawaban responden pada setiap variabel. Pemilihan atas responden yang dilakukan dalam penganalisisan data yang ada adalah seluruh pelanggan PT. Tiki JNE Sub Agen Kayu Agung. Dengan mengambil sampel sebanyak 95 responden. Dalam pembahasan hasil penelitian ini, yang dilakukan dengan menggunakan spss for windows version 22, yang meliputi, statistik responden, uji asumsi dasar, uji asumsi klasik, uji koefisien korelasi, koefisien determinasi Error! Reference source not found.), analisis regresi linier berganda dan uji hipotesis (uji t) dengan interprestasi sebagai berikut :

\section{1) Analisis Data Responden}

Analisis deskripsi variabel penelitian pada tabel 13 terlihat indikator yang digunakan untuk mengukur harga yang kompetitif adalah respon jawaban dengan total skor tertinggi diberikan nilai pernyataan item 1 yaitu Menurut saya harga yang diberikan PT. Tiki JNE Sub Agen Kayu Agung dapat bersaing dengan jasa pengiriman lainnya nilai rata-rata skor yang diberikan adalah 3,06 dengan interprestasi jawaban cukup, dengan nilai seluruh rata-rata skor yang digunakan untuk mengukur indikator harga yang kompetitif menghasilkan rata-rata skor sebesar 2,99 katagori jawaban cukup.

Pada indikator yang digunakan untuk mengukur kesesuaian harga adalah respon jawaban dengan total skor tertinggi diberikan nilai pernyataan item 5 yaitu harga jasa pengiriman PT. Tiki JNE Sub Agen Kayu Agung sesuai dengan kemampuan pelanggan, nilai rata-rata skor yang diberikan adalah 3,41 dengan interprestasi jawaban baik, dengan nilai seluruh rata-rata skor yang digunakan untuk mengukur indikator kesesuaian harga menghasilkan rata-rata skor sebesar 3,14 katagori jawaban cukup. 
Pada indikator yang digunakan untuk mengukur kesesuaian harga dengan kualitas produk adalah respon jawaban dengan total skor tertinggi diberikan nilai pernyataan item 9 yaitu Saya tidak perlu mengeluarkan biaya tambahan saat mengirim barang menggunakan layanan jemput gratis yang di sediakan PT.Tiki JNE Sub Agen Kayu Agung, nilai rata-rata skor yang diberikan adalah 3,27 dengan interprestasi jawaban cukup, dengan nilai seluruh rata-rata skor yang digunakan untuk mengukur indikator kesesuaian harga dengan kualitas pelayanan menghasilkan rata-rata skor sebesar 3,07. katagori jawaban cukup.

Pada indikator yang digunakan untuk mengukur berwujud (Tangible) adalah respon jawaban dengan total skor tertinggi diberikan nilai pernyataan item 2 yaitu PT.Tiki JNE Sub Agen Kayu Agung memberikan layanan pengemasan kiriman sesuai persyaratan pengiriman udara menggunakan bubblepack wrapping se hingga memungkinkan untuk pengiriman barang pecah belah atau perangkat elektronik, dengan nilai ratarata skor yang diberikan adalah 2,60 dengan interprestasi jawaban rendah, nilai seluruh rata-rata skor yang digunakan untuk mengukur indikator berwujud (Tangible) menghasilkan rata-rata skor sebesar 2,51. katagori jawaban rendah.

Pada indikator yang digunakan untuk mengukur empati (Emphaty) adalah respon jawaban dengan total skor tertinggi diberikan nilai pernyataan item 4 yaitu PT.Tiki JNE Sub Agen Kayu Agung menyediakan pelayanan packaging center bagi para pelanggan nilai rata-rata skor yang diberikan adalah 2,69 dengan interprestasi jawaban rendah, dengan nilai seluruh rata-rata skor yang digunakan untuk mengukur indikator Empati (Emphaty) menghasilkan rata-rata skor sebesar 2,32 katagori jawaban rendah.

Pada indikator yang digunakan untuk mengukur daya tanggap (responsiveness) adalah respon jawaban dengan total skor tertinggi diberikan nilai pernyataan item 6 yaitu petugas PT.Tiki JNE Sub Agen Kayu Agung memberikan informasi kepada pelanggan dalam bahasa dan penggunaan kata yang jelas. nilai ratarata skor yang diberikan adalah 2,67 dengan interprestasi jawaban rendah, dengan nilai seluruh rata-rata skor yang digunakan untuk mengukur indikator daya tanggap (responsiveness) menghasilkan ratarata skor sebesar 2,55 dengan interprestasi jawaban rendah. katagori jawaban sangat rendah.

Pada indikator yang digunakan untuk mengukur keandalan (Reliability) adalah respon jawaban dengan total skor tertinggi diberikan nilai pernyataan item 8 yaitu ketepatan waktu sampai pengiriman barang PT.Tiki JNE Sub Agen Kayu Agung baik. nilai rata-rata skor yang diberikan adalah 3,07 dengan interprestasi jawaban cukup, dengan nilai seluruh rata-rata skor yang digunakan untuk mengukur indikator keandalan (Reliability) menghasilkan rata-rata skor sebesar 2,98 dengan interprestasi jawaban cukup.

Pada indikator yang digunakan untuk mengukur jaminan (assurance )adalah bahwa dengan pernyataan respon jawaban dengan skor tertinggi diberikan nilai pernyataan item 10 yaitu PT.Tiki JNE Sub Agen Kayu Agung bertanggug jawab untuk mengganti kerugian yang dialami oleh Pengirim akibat kerusakan dan atau kehilangan kiriman yang timbul akibat kelalaian nilai rata-rata skor yang diberikan adalah 2,73 dengan interprestasi jawaban rendah. dengan nilai seluruh 
rata-rata skor yang digunakan untuk mengukur indikator jaminan (assurance) menghasilkan rata-rata skor sebesar 2,69 dengan interprestasi jawaban rendah.

Variabel yang digunakan dalam penelitian adalah bahwa kepuasan pelanggan indikator yang digunakan untuk mengukur kepuasan pelanggan keseluruhan, berdasarkan hasil penyebaran kuesioner respon jawaban dengan total skor tertinggi diberikan pernyataan item 1 yaitu Saya merasa puas dengan variasi jenis barang layanan PT.Tiki JNE Sub Agen Kayu Agung. Nilai rata-rata yang diberikan jawaban responden adalah sebesar 3,06 dengan katagori jawaban cukup, dengan total nilai rata-rata skor yang digunakan untuk mengukur variabel kepuasan pelanggan menghasilkan rata-rata skor sebesar 3,03. katagori jawaban cukup.

Pada indikator yang digunakan untuk mengukur dimensi kepuasan konsumen adalah respon jawaban dengan total skor tertinggi diberikan nilai pernyataan item 4 yaitu Saya merasa puas dengan fasilitas barang layanan PT.Tiki JNE Sub Agen Kayu Agung dengan menyediakan asuransi atau jaminan keselamatan dalam pengiriman barang, nilai rata-rata skor yang diberikan adalah 3,12 dengan katagori jawaban cukup, nilai seluruh rata-rata skor yang digunakan untuk mengukur indikator dimensi kepuasan konsumen menghasilkan total rata-rata skor sebesar 3,03 katagori jawaban cukup.

Pada indikator yang digunakan untuk mengukur konfirmasi harapan adalah respon jawaban dengan total skor tertinggi diberikan nilai pernyataan item 5 yaitu Pada saat mengirimkan barang di PT.Tiki JNE Sub Agen Kayu Agung sesuai dengan yang di harapkan, nilai rata-rata skor yang diberikan adalah 3,41 dengan katagori jawaban baik, nilai seluruh rata-rata skor yang digunakan untuk mengukur indikator konfirmasi harapan menghasilkan total rata-rata skor sebesar 3,15 katagori jawaban cukup. Pada indikator yang digunakan untuk mengukur minat pembeli ulang adalah respon jawaban dengan total skor tertinggi diberikan nilai pernyataan item 7 yaitu Saya konsisten menggunakan PT.Tiki JNE Sub Agen Kayu

Agung sabagai jasa pengiriman barang, nilai rata-rata skor yang diberikan adalah 3,02 dengan katagori jawaban cukup, nilai seluruh rata-rata skor yang digunakan untuk mengukur indikator minat pembeli ulang menghasilkan total rata-rata skor sebesar 2,97 katagori jawaban cukup.

Pada indikator yang digunakan untuk mengukur kesediaan untuk merekomendasi adalah respon jawaban dengan total skor tertinggi diberikan nilai pernyataan item 9 yaitu dengan sukarela saya akan merekomendasikan PT.Tiki JNE Sub Agen Kayu Agung kepada teman atau rekan, nilai rata-rata skor yang diberikan adalah 3,27 katagori jawaban cukup dengan nilai seluruh rata-rata skor yang digunakan untuk mengukur indikator menunjukan kesediaan untuk merekomendasi menghasilkan total rata-rata skor sebesar 3,10 Agung katagori jawaban cukup.

Berdasarkan penelitian terdahulu Yuda Ramadani (2015: 12) dengan judul "Pengaruh Harga dan Kualitas Pelayanan, Terhadap Kepuasan Pelanggan (Studi Pada PT. Tiki Jalur Nugraha Ekakurir Agen Galunggung Kota Malang)" Hasil penelitian menunjukkan bahwa variabel harga dan kualitas pelayanan secara simultan maupun parsial berpengaruh secara signifikan terhadap kepuasan 
pelanggan PT.TIKI Jalur Nugraha Ekakurir Agen Galunggung Malang. Variabel harga merupakan variabel dominan.

Menurut Riska Hariansah (2013:6) dengan judul "Pengaruh Kualitas Pelayanan Dan Harga Tiket Terhadap Kepuasan Pelanggan Pada PT Kereta Api Indonesia(Persero)Sub Divre III.1 Kertapati Palembang" dengan hasil penelitian variabel independen yaitu kualitas pelayanaan dan harga secara bersama-sama ada pengaruh yang signifikan terhadap variabel dependen kepuasan pelanggan.

Menurut Supriyatin (2014: 9) dengan judul "Pengaruh kualitas pelayanan dan harga terhadap kepuasan pelanggan pada ekspedisi (jasa pengiriman barang) pada CV. Jaya samudra Surabaya, dengan hasil penelitian Uji simultan menunjukkan bahwa kualitas pelayanan dan harga berpengaruh signifikan terhadap kepuasan pelanggan secara simultan. Uji parsial menunjukkan bahwa kualitas pelayanan berpengaruh signifikan terhadap kepuasan pelanggan, Harga berpengaruh signifikan terhadap kepuasan pelanggan.

Berdasarkan peneliti bahwa hasil penelitian menunjukkan bahwa variabel harga dan kualitas pelayanan berpengaruh terhadap kepuasan secara simultan sedangkan variabel harga berpengaruh signifikan terhadap kepuasan pelanggan PT.Tiki Jalur Nugraha Ekakurir Sub Agen Kayu Agung secara parsial dan variabel kualitas pelayanan tidak berpengaruh signifikan terhadap kepuasan pelanggan PT.Tiki Jalur Nugraha Ekakurir Sub Agen Kayu Agung secara parsial.

\section{F. KESIMPULAN DAN SARAN \\ 1. Kesimpulan}

a) Hasil pengujia secara parsial diketahui bahwa nilai signifikansi sebesar $0,000<0,05$ artinya $\mathrm{Ho}$ ditolak, $\mathrm{Ha}$ diterima dapat disimpulkan bahwa terdapat pengaruh antara harga terhadap kepuasan pelanggan.

b) Sedangkan nilai probabilitas signifikansi sebesar 0,550 >0,05 artinya Ho diterima, Ha ditolak maka dapat disimpulkan bahwa tidak terdapat pengaruh antara kualitas pelayanan terhadap kepuasan pelanggan.

c) Sedangkan hasil pengujian secara simultan dengan uji-F variabel harga $\left(X_{1}\right)$ dan kualitas pelayanan $\left(X_{2}\right)$ terhadap variabel kepuasaan pelanggan $(\mathrm{Y})$ karena sig $<\alpha=0,05$ atau $0,000<0,05$ maka Ho ditolak. Ha diterima. Artinya, dengan tingkat kesalahan sebesar $5 \%$ atau 0,05 dapat dinyatakan bahwa harga dan kualitas pelayanan berpengaruh terhadap kepuasan pelanggan secara simultan.

\section{Saran}

Berdasarkan kesimpulan yang diperoleh dalam penelitian ini, maka diajukan saran-saran sebagai pelengkap terhadap hasil penelitian yang dapat diberikan sebagai berikut:
a) Bagi peneliti selanjutnya diharapkan dapat meneliti dengan variabel-variabel lain di luar variabel yang telah diteliti ini agar memperoleh hasil yang lebih bervariatif antara variabel harga dan kualitas pelayanan dapat berpengaruh terhadap kepuasan pelanggan PT. Tiki JNE Sub Agen Kayu Agung.
b) Perusahaan harus mampu memberikan harga yang kompetitif serta meningkatkan kualitas pelayanan yang dengan


memberikan kualitas pelayanan yang baik sesuai dengan harapan pelanggan, sehingga harga dan kualitas pelayanan dapat bersaing lebih baik lagi terhadap kepuasan pelanggan PT. Tiki JNE Sub Agen Kayu Agung.

\section{DAFTAR PUSTAKA}

Abdullah, Thamrin. 2017. Manajemen Pemasaran. Depok : PT RajaGrafindo persada.

Abdurrahman, Nana Herdiana. 2015. Manajemen Strategi Pemasaran. Bandung: CV. Pustaka Setia.

Adam, Muhammad. 2015. Manajemen Pemasaran Jasa. Bandung: Alfabeta.

Ahmad, Kamaruddin. 2015. Akuntansi Manajemen. Depok : PT RajaGrafindo persada.

Alma, Buchari. 2013. Kewirausahaan Untuk mahasiswa Dan Umum. Bandung : Alfabeta.

Heriansah, Riska. 2017. Pengaruh Kualitas Pelayanan Dan Harga Tiket Terhadap Kepuasan Pelanggan Pada PT Kereta Api Indonesia (Persero) Sub Divre III.1 Kertapati Palembang. Fakultas Ekonomi Universitas PGRI, Palembang.

Kasmir. 2014. Kewirausahaan. Depok :PT RajaGrafindo persada.

Kotler , Philip. 2013. Prinsip-Prinsip Pemasaran. Jakarta : Erlangga.

Lovelock, Christopher and Jochen
Wirtz.2010. ServiceMarketing: People, Technology, Strategy. SeventEdition.Singapore PrenticeHall.

Malau, Harman. 2017. Manjemen Pemasaran Teori Dan Aplikasi Pemasaran Era Tradisional Hingga Era Modernisasi Global. Bandung : Alfabeta.

Mubarok, E. Seafuddin. 2015. Ekonomi Manajerial \& Strategis Bisnis. Jakarta : In Media.

Priyatno, Duwi. 2016. Belajar Alat Analisis Data Dan Cara Pengelolaannya Dengan Spss Versi 22. Yogyakarta : Gava Media.

Purnama,

Dimas. (http://dimaspurnama25.blogsport .co.id). 25 September 2016. Pengertian Produk Dan Harga . (Online)

Ramadani, Yuda. 2015. Pengaruh Harga dan Kualitas Pelayanan, Terhadap Kepuasan Pelanggan (Studi Pada PT. Tiki Jalur Nugraha Ekakurir Agen Galunggung Kota Malang). Fakultas Ekonomi dan Bisnis, Universitas Brawijaya

Santoso, Singgih. 2012. Panduan lengkap SPSS Versi 20. Jakarta : PT. Elex Media Komputindo.

Sudaryono. 2016. Manajemen Pemasaran Teori Dan Implementasi. Yogyakarta : C.V Andi Offset .

Sugiyono. 2015. Metode Penelitian Kuantitatif, Kualitatif Dan $R \& D$. Bandung : Alfabetha. 
Supriyatin. 2014. Pengaruh Kualitas Pelayanan Dan Harga Terhadap Kepuasan Pelanggan Pada Ekspedisi (Jasa Pengiriman Barang) Pada CV. Jaya Samudra Surabaya. Sekolah Tinggi IImu Ekonomi Indonesia (STIESIA), Surabaya.

Swastha, Basu.2015. Manajemen Penjualan. Yogyakarta : BPFE.

Tjiptono,Fandy. 2014. Manajemen Jasa. Yogyakarta : C.V Andi Offset .

Wiratna, V. Sujarwani. 2014. Metode Penelitian. Yogyakarta : PT. Pustaka Baru. 